\title{
Prevention of Biomaterial Infection by Pre-Operative Incubation with Human Cells
}

\section{Pérez Tanoira, Ramón}

2017-04

Pérez Tanoira , R, Aarnisalo , A A, Eklund , K, Han , X, Soininen , A, Tiainen , V-M , Esteban , J \& Kinnari , T J 2017 , ' Prevention of Biomaterial Infection by Pre-Operative Incubation with Human Cells ' , Surgical Infections , vol. 18 , no. 3 , pp. 336-344 . https://doi.org/10.1089/sur.2016.26

http://hdl.handle.net/10138/234687

https://doi.org/10.1089/sur.2016.263

unspecified

publishedVersion

Downloaded from Helda, University of Helsinki institutional repository.

This is an electronic reprint of the original article.

This reprint may differ from the original in pagination and typographic detail.

Please cite the original version. 


\title{
Prevention of Biomaterial Infection by Pre-Operative Incubation with Human Cells
}

\author{
Ramón Pérez-Tanoira, Antti A. Aarnisalo, Kari K. Eklund, ${ }^{2,5}$ Xia Han, ${ }^{2}$ Antti Soininen,,4 \\ Veli-Matti Tiainen, ${ }^{3,4}$ Jaime Esteban, and Teemu J. Kinnari ${ }^{1}$
}

\begin{abstract}
Background: Cells of tissues and biofilm forming bacteria compete for the living space on the surface of an implant. We hypothesized the incubation of the implant (titanium, polydimethylsiloxane, and polystyrene surface) with human cells before implantation as a strategy to prevent bacterial adhesion and biofilm formation. Methods: After 24 hours of incubation with human osteogenic sarcoma SaOS-2 cells $\left(1 \times 10^{5}\right.$ cells $\left./ \mathrm{mL}\right)$, the materials were incubated for 4.5 hours or two days with Staphylococcus aureus in serial 1:10 dilutions of $10^{8}$ colony-forming units $/ \mathrm{mL}$. The bacterial adherence and biofilm biomass on materials pre-incubated with SaOS-2 cells were compared with our previous results on materials incubated only with bacteria or in simultaneous coculture of SaOS-2 cells and $S$. aureus. Fluorescent microscopy and crystal violet stain were used. The number of viable SaOS-2 and bacterial cells present was tested using colorimetric methods (MTT, LDH) and drop plate method, respectively.

Results: The pre-treatment with human cells was associated with a reduction of bacterial colonization of the biomaterial at 4.5 hours and 48 hours compared with the non-pre-treated materials. The presence of bacteria decreased the number of viable human cells on all materials. (Supplementary Fig. 1; see online supplementary materials at www.liebertpub.com/sur).
\end{abstract}

Conclusions: These results suggest that the pre-operative incubation of prostheses with host cells could prevent infection of biomaterials.

Keywords: bacterial adherence; biofilm; biomaterial; pre-operative incubation; race for the surface

$\mathbf{T}$ HE TWO LEADING CAUSES of failure for prostheses are aseptic loosening and prosthetic infection. With the increased number of implantations, the absolute number of complications is increasing inevitably [1-3]. The presence of a foreign body automatically initiates the race between bacteria and host cells to colonize the surface of the implant [4]. Bacteria that adhere to implanted medical devices or to damaged tissue form a thin layer known as a biofilm [5]. The ability to grow in a biofilm form enables the bacteria to protect themselves from host defense, antibiotic agents, and biocides, making it difficult to manage these infections; thus, it requires long periods of antibiotic therapy and often repeated surgical procedures, all leading to a clinical and economic burden [5-7].
Research on anti-biofilm implant properties focuses on materials loaded or coated with anti-adhesive/anti-bacterial substances or surfaces with nanostructures [8-13]. Active coatings release pre-incorporated bactericidal agents such as antibiotic agents, antiseptics such as silver ions or growth factors, chemokines, and peptides that prevent the infection. The spread of some of these substances into the neighboring tissues, however, could provide a consequent risk of inducing bacterial resistance or cytotoxicity [14]. The most recent approaches, so-called passive coatings, appear promising, because they diminish the rate of infections by enhancing tissue compatibility or integration, or by directly inhibiting bacterial adhesion [15-17].

\footnotetext{
${ }^{1}$ Department of Otorhinolaryngology - Head and Neck Surgery, Helsinki University Hospital and University of Helsinki, Helsinki, Finland.

${ }^{2}$ Clinicum, University of Helsinki, Helsinki, Finland.

${ }^{3}$ ORTON Research Institute, Helsinki, Finland.

${ }^{4}$ ORTON Orthopedic Hospital, Helsinki, Finland.

${ }^{5}$ Department of Rheumatology, Helsinki University Hospital and University of Helsinki, Helsinki, Finland.

${ }^{6}$ Clinical Microbiology, IIS-Fundación Jiménez Díaz, Madrid, Spain.
} 
Adherence and colonization by either bacterial cells or tissue cells on biomaterials have been studied mainly as separate phenomena $[1,8,9,18]$. During the development of new biomaterial coating strategies, however, these two issues must be evaluated in parallel, because it is essential to achieve a successful long-term outcome. According to our previous study, in the race between bacteria and tissue cells for the implant surface, the presence of either one reduces biomaterial adhesion and the viability of the other, which implies that host-cell integration on implant surfaces reduces bacterial contamination [19].

Micro-organisms frequently infect an implant surface during surgical procedures and start to compete for the surface before tissue integration [20]. We hypothesized that incubation of implants with host cells before implantation may be a way to reduce the living space available for the bacteria and would thus help to avoid the bacterial adhesion and consequently the infection of biomaterials, eluding the use of antibiotic-loaded biomaterials, which confers a risk for bacterial antibiotic resistance [21,22].

\section{Methods}

Materials

Magnetron sputtering technique was used for deposition of titanium samples as described previously [9]. The 2-mm thick bulk polydimethylsiloxane (PDMS) polymer sheets of size $9 \times 9 \mathrm{~mm}$ were obtained from a commercial supplier of industrial polymers (ETRA, Helsinki, Finland). Average surface roughness $\mathrm{Ra}$ was approximately $300-400 \mathrm{~nm}$ for both materials. The 24-well cell culture plates of polystyrene (PS) (Thermo Scientific Nunc, Roskilde, Denmark) were used as control material.

\section{Co-culture of human cells and staphylococci}

Culture of human cells. Human osteosarcoma SaOS-2 cells (ECACC, Salisbury, Wiltshire, UK) were grown as described by Perez-Tanoira et al. [19]. Human cells were seeded at $10^{5}$ cells $/ \mathrm{mL}$ on (a) titanium, (b) PDMS, and (c) directly on 24-well PS cell culture plates and were incubated in a total volume of $2 \mathrm{~mL}$ of MEM (minimal essential medium) supplemented with $10 \%$ heat-inactivated fetal bovine serum (FBS) and 1\% L-glutamine (Life Technologies, Grand Island, NY) containing $500 \mathrm{IU} / \mathrm{mL}$ penicillin and $0.1 \mathrm{mg} / \mathrm{mL}$ streptomycin for 24 hours at $+37^{\circ} \mathrm{C}$ in $20 \%$ or $6 \% \mathrm{O}_{2}$ in a humidified incubator.

Culture of staphylococci. Staphylococcal adhesion experiments were performed as described by Kinnari et al. [12]. The S. aureus 15981 [23] isolated at the Microbiology Department of the University Clinics of Navarra, Spain, was selected because it has a strong biofilm production phenotype and a well-described antibiotic susceptibility profile. Bacteria were diluted in sterile $10 \mathrm{mM}$ phosphate-buffer saline (PBS) to obtain suspension with a $10^{8}$ colony-forming unit (CFU)/mL. The optical density of the bacterial suspension was measured at a wavelength of $550 \mathrm{~nm}$ with a spectrophotometer according to the McFarland standard (BioMerieux, SA Lyon, France).

Co-culture of human cells and staphylococci. Serial 1:10 dilutions were made from $10^{8} \mathrm{CFU} / \mathrm{mL} S$. aureus suspension to obtain the bacterial concentrations of $10^{7}, 10^{6}, 10^{5}, 10^{4}$, $10^{3}$, and $10^{2} \mathrm{CFU} / \mathrm{mL}$ in a total volume of $2 \mathrm{~mL}$ of MEM:PBS (1:1), MEM including 5\% FBS, 0.5\% L-glutamine (Life Technologies). Based on our previous study [19], MEM:PBS medium was chosen to be used in the studies. The different bacterial dilutions were incubated for 4.5 or 48 hours on (a) titanium, (b) PDMS, and directly on (c) 24-well PS cell culture plates. In the simultaneous co-culture, the studied biomaterial surfaces were maintained in the same medium simultaneously with $10^{5} \mathrm{SaOS}-2$ cells/mL [19]. In the case of materials pre-incubated with SaOS-2 cells, after the cell medium was removed and samples were washed three times with PBS to remove any non-adherent human cell, they were on the same $S$. aureus media.

A negative control ( $1 \mathrm{~mL}$ of PBS $+1 \mathrm{~mL}$ of MEM), bacterial control $\left(1 \mathrm{~mL}\right.$ of $10^{8} \mathrm{CFU} / \mathrm{mL}$ of $S$. aureus on PBS $+1 \mathrm{~mL}$ of MEM), a cellular control $\left(1 \mathrm{~mL}\right.$ of $10^{5}$ cells $/ \mathrm{mL}$ on MEM $+1 \mathrm{~mL}$ of PBS after 4.5 hours, [24+4.5] hours, 48 hours, or $(24+48)$ hours) were also included. In each experiment, a total of 10 samples of titanium, PDMS, and well plates were covered with each of the different dilutions, and incubated first for 4.5 hours at $37^{\circ} \mathrm{C}$ to allow cell and bacterial adhesion and then up to 48 hours for biofilm formation and cell adhesion in a static model.

\section{Assessment of cell proliferation and cytotoxicity}

Fluorescence microscopy. After incubation with the different dilutions of bacteria and human cells, samples were washed three times with PBS. The dried plates were stained for two minutes with a rapid fluorescence staining method using Acridine Orange (BD Diagnostics, Sparks, MD). Images were taken with a fluorescent light Leica DM6000 B/M research microscope (Leica Microsystems, Wetzlar, Germany) equipped with Leica DFC420 digital camera (Leica Microsystems), with $10 \times$ magnification and identical settings and parameters for photographing of all samples. On each plate, eight fields were viewed and photographed. All experiments were performed in triplicate.

Assay for SaOS-2cell viability. Human cell viability was assessed by 3-(4,5-dimethylthiazolyl-2)-2,5-diphenyltetrazolium bromide tetrazolium (MTT) dye assay based on mitochondrial ability to transform soluble MTT to its insoluble purple product, formazan. After 4.5 hours or 48 hours, culture medium was replaced by $10 \mathrm{mcL}$ of $5 \mathrm{mg} / \mathrm{mL}$ MTT (EMD Millipore Corp., Billerica, MA) dissolved in dimethyl sulfoxide (DMSO) (MP Biomedicals, LLC, Illkirch, France) for four hours. Then, cells were suspended by adding $300 \mathrm{mcL}$ of detergent reagent at $+22^{\circ} \mathrm{C}$ during two hours. Aliquots of $200 \mathrm{mcL}$ were then transferred to 96-well plates for measurement of absorbance using CHAMELEON V Multilabel Microplate Reader (Hidex, Turku, Finland) with $570 \mathrm{~nm}$ test and $690 \mathrm{~nm}$ reference wavelengths.

Lactate dehydrogenase (LDH) cytotoxicity assay. Cytotoxicity was determined by assessing the release of cytosolic enzyme LDH into the supernatant medium. The LDH assay was performed using tetrazolium dye-based CytoTox 96 Non-Radioactive Cytotoxicity Assay (Promega, Madison, WI) according to the manufacturer's instructions. Supernatants (experimental LDH release), samples treated with the 
lysis solution (maximal LDH release), and non-treated control samples (spontaneous LDH release) were transferred to 96-well plates. The absorbance at $490 \mathrm{~nm}$ was read using a microplate reader. Percentage of cytotoxicity values was calculated using the formula $(100 \times[$ experimental $\mathrm{LDH}$ release - spontaneous LDH release/maximum LDH releasespontaneous release]) [24].

\section{Bacterial adherence and biofilm formation}

Bacterial adherence and biofilm formation results obtained in this study from materials pre-incubated with SaOS-2 cells during 24 hours were compared with results of our earlier study obtained from materials incubated with $S$. aureus only or in a co-culture with SaOS-2 cells [19]. After 4.5 hours and 48 hours incubation time, samples were washed three times with $250 \mathrm{mcL}$ of PBS to remove non-adherent bacteria and cells, followed by treatment with $400 \mathrm{mcL}$ of trypsin. To compare the results, all the materials, incubated or not with SaOS-2 cells, were treated with trypsin to take into consideration the possible effect of trypsin. Controls were performed simultaneously with the tests to avoid bacterial adaptation to laboratory conditions.

Drop plate method. All materials were sonicated in an ultrasonic bath USC100T (VWR, Leuven, Belgium) at $45 \mathrm{kHz}$ with a power output of $300 \mathrm{~W}$ for five minutes in $2.5 \mathrm{~mL}$ of PBS as described earlier [25,26]. The number of viable bacteria in each sonication product was quantified by the drop plate method [27]. The bacterial count obtained from co-cultures was compared with the results of bacterial monocultures. The experiments were all performed in sets of three.

Crystal violet. Based on the methods of Pitts et al. [28] and Stepanovic et al. [29], at the end of the incubation period, each material was washed to remove all non-adherent bacteria. The remaining attached bacteria were stained for 15 minutes with $1 \%$ crystal violet stain. Excess stain was rinsed off by placing the plate under running tap water. The dye bound to the adherent cells was re-dissolved in $300 \mathrm{mcL}$ of $95 \%$ ethanol. Aliquots of $200 \mathrm{mcL}$ were then transferred to 96-well plates for measurement of absorbance using Chameleon-V microplate reader with $570 \mathrm{~nm}$ (test) and $690 \mathrm{~nm}$ (reference) wavelengths.

\section{Statistical analysis}

The statistical analyses were performed with four independent experiments per test condition. The data are reported as (mean \pm standard deviation [SD]). Data were analyzed using IBM SPSS Statistics for Windows Version 22.0 software (IBM Corp., Armonk, NY). Non-parametric tests were used. Mann-Whitney or Wilcoxon tests were used for two samples, and the Kruskal-Wallis test was used for more than two samples.

\section{Results}

\section{Effects of bacterial exposure on number of viable cells and on cytotoxicity}

Figure 1 shows representative images of the titanium surfaces incubated with human cells for 4.5 hours or 48 hours in the presence or absence of bacteria. When SaOS-2 cells were pre-incubated with the biomaterial for 24 hours before addition of bacteria, the number of attached $S$. aureus on biomaterials was clearly lower than with the same bacterial density without cells (panels a and f), or when cells and bacteria were added simultaneously ( $b$ and $g$ ). The data of panels (a, b, c, f, g, and h) are presented for comparison and are obtained from our previous study [19]. When bacteria were added, the number of viable SaOS-2 cells on biomaterial was significantly reduced both in simultaneous co-culture (panels b and g) and materials pre-incubated with SaOS-2 cells (panels d and i), as compared with SaOS cells incubated alone, both after 4.5 and 48 hours of culture (panels c, e, h, and $\mathrm{j}$ ).

The results were confirmed for all bacterial densities by using MTT proliferation assay. The reduction was not affected by the bacterial density for PS $(p=0.685$ and $p=0.100$, Kruskal-Wallis test, for 4.5 hours and 48 hours, respectively) or PDMS $(p=0.158$ and 0.246 for 4.5 hours and 48 hours, respectively). This was visible on the titanium surface, however, where $\mathrm{CFU} / \mathrm{mL}>10^{6}$ diminished number of viable SaOS-2 cells compared with $\mathrm{CFU}=10^{2}$. There were no statistically significant differences on number of attached human cells on titanium surfaces for $\mathrm{CFU}=10^{3}-10^{8}(\mathrm{p}=0.187$ and 0.550 for 4.5 hours and 48 hours, respectively).

Figure 2 shows a statistically significant reduction of the percentage of viable SaOS-2 cells after 48 hours compared with 4.5 hours for all bacterial densities and materials with respect to the materials incubated only with $\mathrm{SaOS}-2$ cells.

Bacteria were cytotoxic to the pre-incubated SaOS-2 cells as evidenced by increased $\mathrm{LDH}$ release from cells on all materials studied (Fig. 3). Cytotoxicity was not dependent of the bacterial density for PS $(p=0.494$ and $p=0.275$ for 4.5 hours and 48 hours, respectively) and PDMS ( $p=0.361$ and $p=0.457$ for 4.5 hours and 48 hours, respectively). Only in the case of cells incubated on titanium for 4.5 hours, the presence of $S$. aureus $\mathrm{CFU} / \mathrm{mL} \geq 10^{6}$ increased the death of SaOS-2 cells $\left(\mathrm{p}=0.388\right.$ for $\mathrm{CFU} / \mathrm{mL}=10^{2}-10^{5}$ after 4.5 hours and $\mathrm{p}=0.382$ for $\mathrm{CFU} / \mathrm{mL}=10^{2}-10^{8}$ after 48 hours). On the other hand, the percentage of cell cytotoxicity after 48 hours was higher compared with the same bacterial density and materials after 4.5 hours, only with the exception of titanium for $\mathrm{CFU} \geq 10^{7}\left(\mathrm{p}=0.248\right.$ for $\left.\mathrm{CFU} / \mathrm{mL}=10^{7}-10^{8}\right)$.

\section{Incubation of biomaterial with human SaOS-2 cells reduces the viability of bacterial cells and the biofilm formation}

The pre-incubation of prosthetic materials with SaOS-2 cells reduced bacterial adherence and biofilm biomass compared with the materials incubated only with bacteria or with simultaneous co-culture with $S$. aureus and SaOS-2 cells as detected by crystal violet. This was observed with all bacterial concentrations with the exception of simultaneous coculture at 4.5 hours, on PS with CFU/mL $\geq 10^{7}(\mathrm{p}=0.080$ and 0.561 with $\mathrm{CFU} / \mathrm{mL}=10^{7}$ and $10^{8}$, respectively), and titanium with $\mathrm{CFU} / \mathrm{mL}=10^{8}(\mathrm{p}=0.081)$ and at 48 hours on PS with $\mathrm{CFU} / \mathrm{mL}=10^{8}(\mathrm{p}=0.149)$ (Fig. 4).

As demonstrated in Figure 5, the amount of viable bacteria in all materials and with different concentrations of bacteria was reduced by the pre-incubation with SaOS-2 as compared with the materials incubated only with $S$. aureus or in simultaneous co-culture (Fig. 5). 

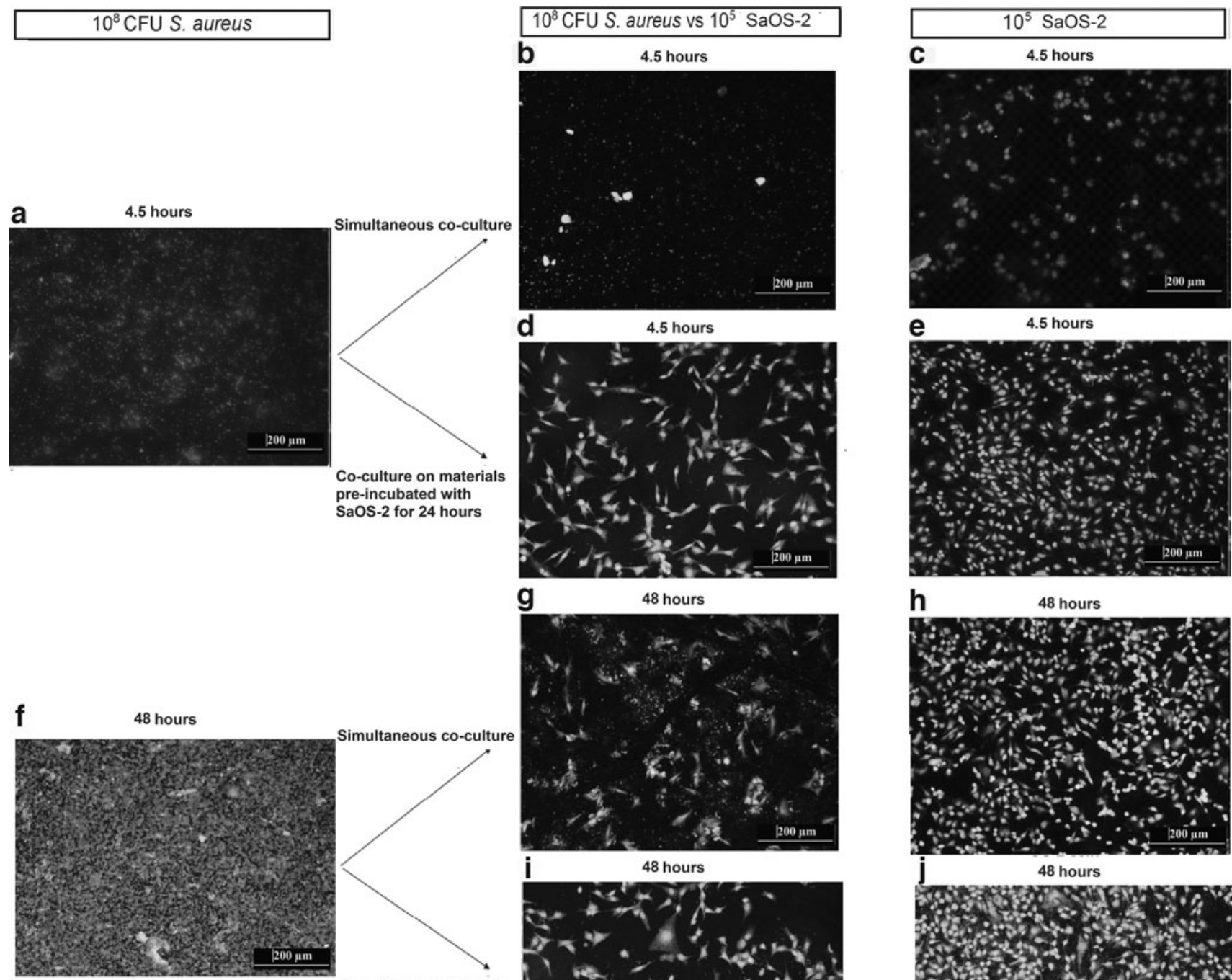

Co-culture on materials pre-incubated with SaOS-2 for 24 hours
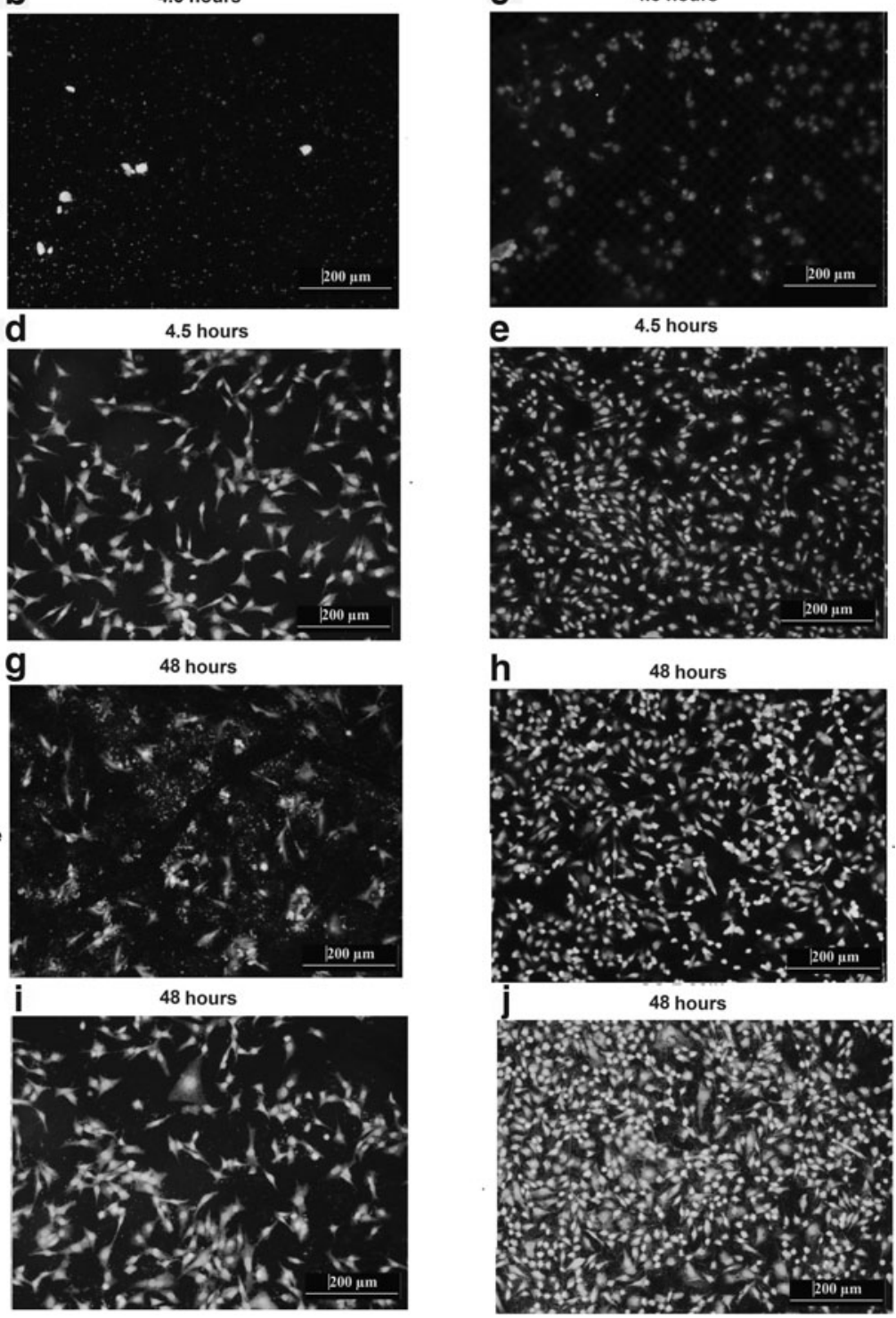

FIG. 1. Representative fluorescence microscope images of titanium surface incubated with $10^{8}$ colony-forming units $(\mathrm{CFU}) /$ $\mathrm{mL}$ of Staphylococcus aureus (a), simultaneous co-culture of $10^{5} \mathrm{SaOS}-2$ cells $/ \mathrm{mL}$ and S. aureus (b), or $10^{5} \mathrm{SaOS}-2$ cells/ $\mathrm{mL}$ (c) for 4.5 hours or for 48 hours (f-h). Panels d,e and i,j had similar conditions except that SaOS-2 cells had been preincubated for 24 hours before adding $S$. aureus. Incubation times in d,e were 4.5 hours and in i,j, they were 48 hours. The samples were stained with Acridine Orange (BD Diagnostics, Sparks, MD).

\section{Discussion}

The present findings support the hypothesis that preoperative incubation of biomaterial with osteoblast host cells could prevent infection of the biomaterial. We found that in vitro, after tissue cells have adhered to the surface of the biomaterial, bacteria cells are more unlikely to displace them. This seems to prevent the colonization of the implant surface with circulating planktonic bacteria that can lead to biofilm development. Otherwise, within the high dense bacterial population, efficient horizontal transfer of resistance and virulence genes takes place leading to the spread of resistance to conventional antibiotic therapies necessitating the use of alternative agents [30,31].
Much of the recent research work in this field has focused on the design of coatings that prevent infection while ignoring bone mineralization or vice versa [1]. The promotion of tissue integration as a mean of protection against infection has been poorly studied $[32,33]$. According to Subbiahdoss et al. [33], if an implant is integrated rapidly by the tissue to levels above critical cell surface coverage, it will be protected effectively against post-operative contaminating bacteria. Dexter et al. [32], who considered separately the presence of human cells and bacteria, suggested that by controlling the density of proteins or ligands on a surface, cell adhesion and surface coverage could be stimulated without stimulating bacterial adhesion, hence reducing the likelihood of infection. 


\section{Polystyrene}

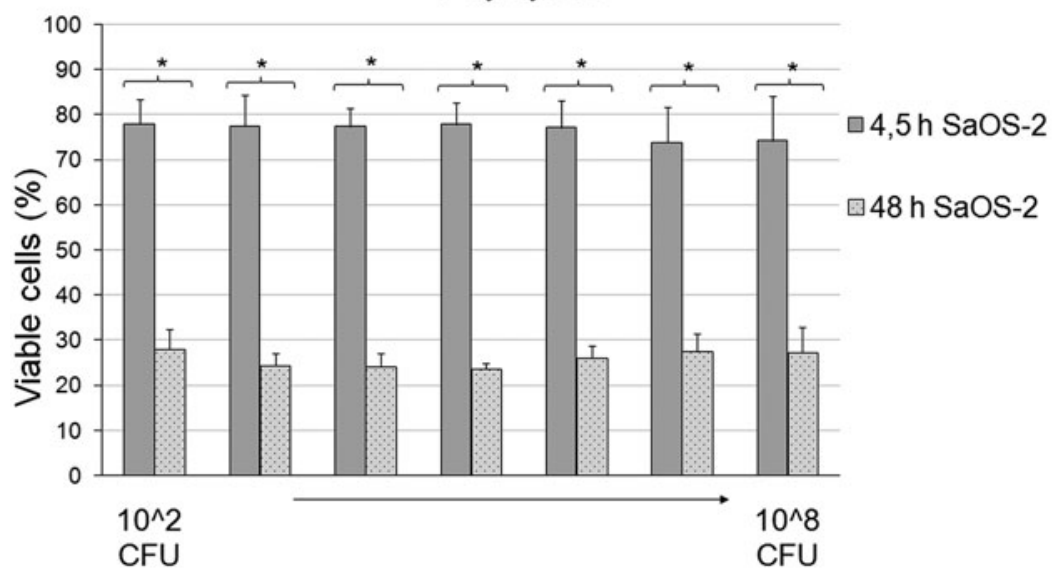

Titanium
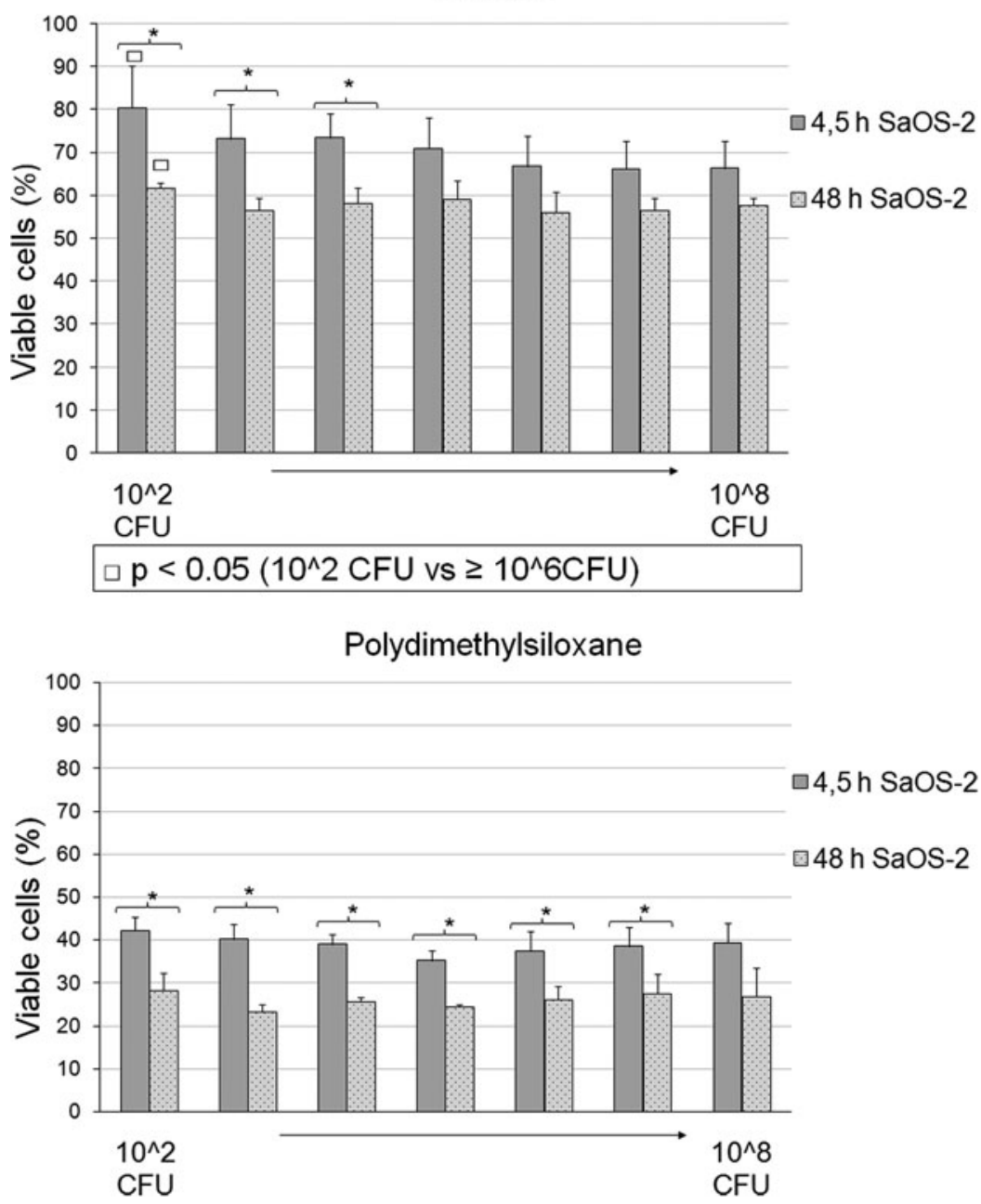

FIG. 2. Percentage of viable SaOS-2 cells pre-incubated for 24 hours (measured by MTT assay) on polystyrene, titanium, and polydimethylsiloxane in the presence or absence of different concentrations of Staphylococcus aureus after incubation of 4.5 hours and 48 hours. Results are means \pm standard deviation of four determinations in quadruplicate culture. *Statistically significant means $\mathrm{p}<0.05$ for 4.5 hours compared with 48 hours unless otherwise mentioned. $\mathrm{CFU}=$ colony-forming units.

Our results are in good agreement with the important implication of these findings. Because micro-organisms are frequently introduced on an implant surface during surgery, however, they start the race for the surface with an advantage. We decided to try to prevent the peri-operative contamination by adhering the human cells to the surface before contamination [34].

We need to develop strategies in which bacterial adhesion on biomaterial is avoided; less than $10^{2} \mathrm{CFU}$ of $S$. aureus is needed to develop biofilm in an implant and establish a 

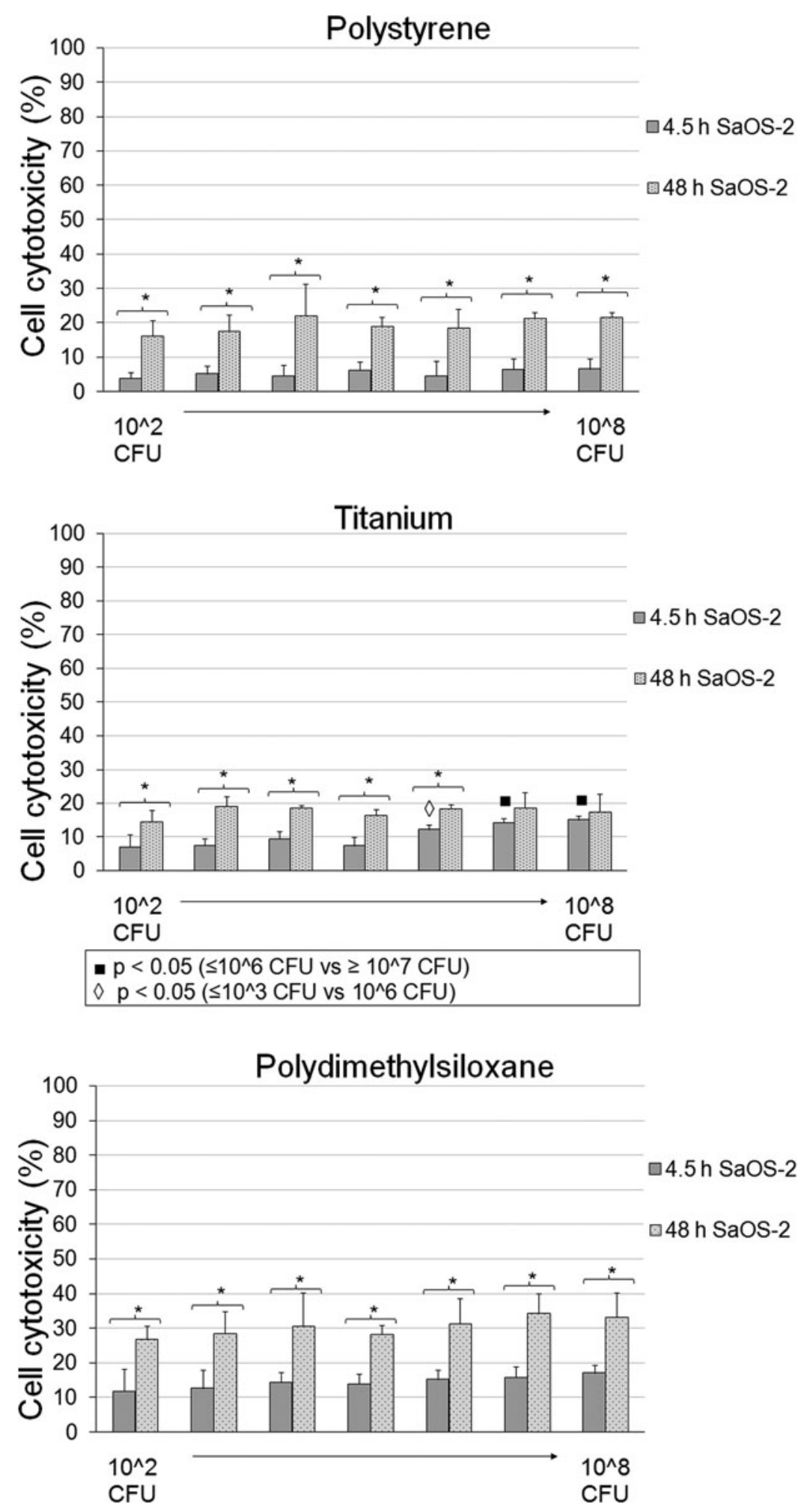

FIG. 3. Lactate dehydrogenase activity levels of media of SaOS-2 pre-incubated for 24 hours on polystyrene, titanium, and polydimethylsiloxane in the presence or absence of different concentrations of Staphylococcus aureus after 4.5 hours or 48 hours. Results are means \pm standard deviation of four determinations in quadruplicate culture. *Statistically significant means $\mathrm{p}<0.05$ for 4.5 hours compared with 48 hours unless otherwise mentioned. $\mathrm{CFU}=$ colony-forming units. 

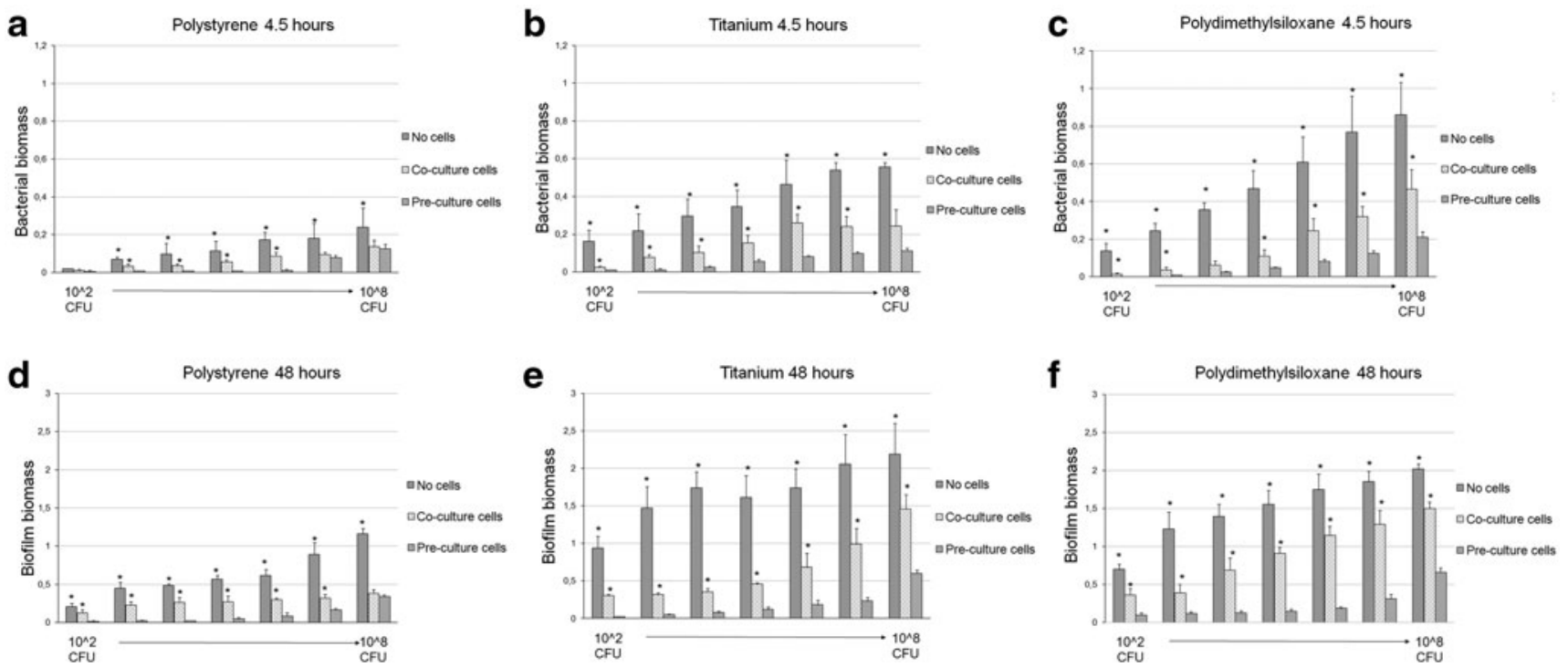

FIG. 4. Absorbance value of crystal violet assay after 4.5 hours and 48 hours incubation. Mean and standard deviation are shown. *Statistically significant means $\mathrm{p}<0.05$ versus all other situations unless otherwise mentioned. $\mathrm{CFU}=\mathrm{colony-}$ forming units.

prosthesis infection [35,36]. Several studies have shown a reduction of bacterial adherence at high bacterial densities, $\mathrm{CFU} / \mathrm{mL} \geq 10^{6}$; however, the clinical relevance of such high bacterial densities may be questionable. We found that at longer incubation times, the presence of bacteria produces a higher decrease of osseointegration. We tested serial 1:10 dilutions from $10^{2} \mathrm{CFU} / \mathrm{mL}$ up to $10^{8} \mathrm{CFU} / \mathrm{mL}$. Our results show a biomaterial-associated infection prevention by preoperative incubation with human cells when materials are contaminated with bacterial density related to clinical circumstances $\left(10^{2}-10^{4} \mathrm{CFU} / \mathrm{mL}\right)$.

Starting from the lowest bacterial density, the presence of $S$. aureus diminished osteoblast viability and proliferation, even when bacteria were not detected or isolated from the surface of the implant. The fact that it was not dependent of the bacterial density, however, is in agreement with our previous study [19], while it contrasts with that of Subbiahdoss et al. [33], who found that once cell surface coverage exceeded a critical value, contaminating bacteria ceased to negatively affect cell growth.

These results are not conclusive, but we think this study can be used as a proof of concept. One question, still unanswered, is how the pre-operative incubation with autologous osteoblast cells affects the tissue integration of the implant. In the future, we will assess the use of primary osteoblast cells. Compared with SaOS-2 cells, longer
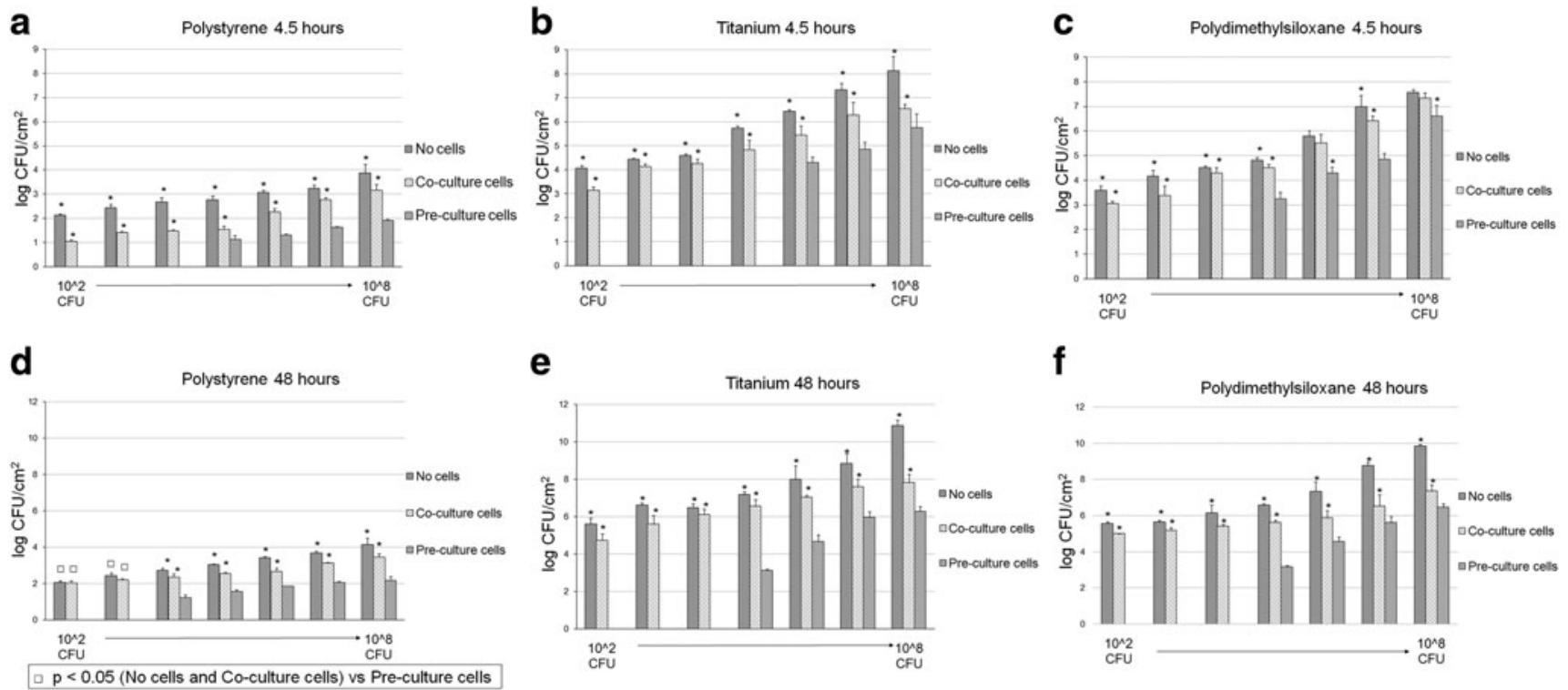

FIG. 5. Colony-forming units as determined by viable cell count after 4.5 hours and 48 hours incubation. Mean and standard deviation are shown. *Statistically significant means $\mathrm{p}<0.05$ versus all other conditions unless otherwise mentioned. $\mathrm{CFU}=$ colony-forming units. 
pre-incubation time will be required with primary cells to obtain coverage of most of the surface area of the implant. Future research will involve the effects of phagocytosis, considering the presence of macrophages in co-culture with bacteria and osteoblasts. These findings could also be proved using clinically significant bacterial strains isolated from prosthetic infections, which may show more virulence against human cells.

Implant infection is a rising problem especially in devices implanted to bone contact such as in orthopedic, maxillofacial, and ear surgical procedures. The implantation to bone contact is increasing and involves patients of all ages. We tested materials mainly used in bone contact, despite the fact that the rate of infection is lower compared with implants used elsewhere [1]. In the next stages of our research, it would be interesting to investigate whether biomaterials such as polytetrafluoroethylene that are used more for soft tissue implantation would show similar prevention of infection when pre-operatively incubated with cells from soft tissue such as fibroblasts.

\section{Conclusions}

The concept of tissue integration over microbial colonization provides an important guideline for which "in vitro" assays may be indispensable tools and should be part of the development process of any tissue engineered constructs and devices [37]. It can be argued that the prevention of bacterial adhesion without drugs, through pre-operative incubation of prostheses with host cells, may be one of the most effective ways to reduce biomaterial infections.

\section{Acknowledgments}

This work was supported by the Department of Otorhinolaryngology - Head and Neck Surgery of Helsinki University Hospital and University of Helsinki.

\section{Author Disclosure Statement}

No competing financial interests exist.

\section{References}

1. Raphel J, Holodniy M, Goodman SB, Heilshorn SC. Multifunctional coatings to simultaneously promote osseointegration and prevent infection of orthopaedic implants. Biomaterials 2016;84:301-314.

2. Kurtz S, Ong K, Lau E, et al. Projections of primary and revision hip and knee arthroplasty in the United States from 2005 to 2030. J Bone Joint Surg Am 2007;89:780-785.

3. Metsemakers WJ, Moriarty TF, Nijs S, et al. Influence of implant properties and local delivery systems on the outcome in operative fracture care. Injury 2016;47:595-604.

4. Gristina AG, Naylor P, Myrvik Q. Infections from biomaterials and implants: A race for the surface. Med Prog Technol 1988;14:205-224.

5. Stewart PS, Costerton JW. Antibiotic resistance of bacteria in biofilms. Lancet 2001;358:135-138.

6. Darouiche RO. Device-associated infections: A macroproblem that starts with microadherence. Clin Infect Dis 2001; 33:1567-1572.

7. Darouiche RO. Treatment of infections associated with surgical implants. N Engl J Med 2004;350:1422-1429.
8. Perez-Tanoira R, Kinnari TJ, Hyyrynen T, et al. Effects of S53P4 bioactive glass on osteoblastic cell and biomaterial surface interaction. J Mater Sci Mater Med 2015;26:246.

9. Perez-Tanoira R, Garcia-Pedrazuela M, Hyyrynen T, et al. Effect of S53P4 bone substitute on staphylococcal adhesion and biofilm formation on other implant materials in normal and hypoxic conditions. J Mater Sci Mater Med 2015; 26:239.

10. Saenz de Viteri V, Barandika G, Bayon R, et al. Development of Ti-C-N coatings with improved tribological behavior and antibacterial properties. J Mech Behav Biomed Mater 2015;55:75-86.

11. Perez-Tanoira R, Horwat D, Kinnari TJ, et al. Bacterial adhesion on biomedical surfaces covered by yttria stabilized zirconia. J Mater Sci Mater Med 2016;27:6.

12. Kinnari TJ, Soininen A, Esteban J, et al. Adhesion of staphylococcal and Caco-2 cells on diamond-like carbon polymer hybrid coating. J Biomed Mater Res A 2008;86: 760-768.

13. Perez-Jorge C, Conde A, Arenas MA, et al. In vitro assessment of Staphylococcus epidermidis and Staphylococcus aureus adhesion on $\mathrm{TiO}(2)$ nanotubes on Ti-6Al-4V alloy. J Biomed Mater Res A 2012;100:1696-1705.

14. Arciola CR, Campoccia D, Speziale P, et al. Biofilm formation in Staphylococcus implant infections. A review of molecular mechanisms and implications for biofilmresistant materials. Biomaterials 2012;33:5967-5982.

15. Gristina AG. Biomaterial-centered infection: Microbial adhesion versus tissue integration. Science 1987;237:15881595.

16. Boelens JJ, Dankert J, Murk JL, et al. Biomaterialassociated persistence of Staphylococcus epidermidis in pericatheter macrophages. J Infect Dis 2000;181:1337-1349.

17. Goodman SB, Yao Z, Keeney M, Yang F. The future of biologic coatings for orthopaedic implants. Biomaterials 2013;34:3174-3183.

18. Sun J, Zhu Y, Meng L, et al. Electrophoretic deposition of colloidal particles on $\mathrm{Mg}$ with cytocompatibility, antibacterial performance, and corrosion resistance. Acta Biomater 2016;45:387-398.

19. Perez-Tanoira R, Han X, Soininen A, et al. Competitive colonization of prosthetic surfaces by staphylococcus aureus and human cells. J Biomed Mater Res A 2017;105:62-72.

20. Subbiahdoss G, Kuijer R, Grijpma DW, et al. Microbial biofilm growth vs. tissue integration: "The race for the surface" experimentally studied. Acta Biomater 2009;5: 1399-1404.

21. van de Belt H, Neut D, Schenk W, et al. Infection of orthopedic implants and the use of antibiotic-loaded bone cements. A review. Acta Orthop Scand 2001;72:557-571.

22. Campoccia D, Montanaro L, Speziale P, Arciola CR. Antibiotic-loaded biomaterials and the risks for the spread of antibiotic resistance following their prophylactic and therapeutic clinical use. Biomaterials 2010;31:6363-6377.

23. Valle J, Toledo-Arana A, Berasain C, et al. SarA and not sigmaB is essential for biofilm development by Staphylococcus aureus. Mol Microbiol 2003;48:1075-1087.

24. Chan FK, Moriwaki K, De Rosa MJ. Detection of necrosis by release of lactate dehydrogenase activity. Methods Mol Biol 2013;979:65-70.

25. Esteban J, Gomez-Barrena E, Cordero J, et al. Evaluation of quantitative analysis of cultures from sonicated retrieved orthopedic implants in diagnosis of orthopedic infection. J Clin Microbiol 2008;46:488-492. 
26. Kobayashi N, Bauer TW, Tuohy MJ, et al. Brief ultrasonication improves detection of biofilm-formative bacteria around a metal implant. Clin Orthop Relat Res 2007;457: 210-213.

27. Herigstad B, Hamilton M, Heersink J. How to optimize the drop plate method for enumerating bacteria. J Microbiol Methods 2001;44:121-129.

28. Pitts B, Hamilton MA, Zelver N, Stewart PS. A microtiterplate screening method for biofilm disinfection and removal. J Microbiol Methods 2003;54:269-276.

29. Stepanovic S, Vukovic D, Dakic I, et al. A modified microtiter-plate test for quantification of staphylococcal biofilm formation. J Microbiol Methods 2000;40:175179.

30. Costerton JW, Montanaro L, Arciola CR. Biofilm in implant infections: Its production and regulation. Int $\mathrm{J}$ Artif Organs 2005;28:1062-1068.

31. Trampuz A, Zimmerli W. New strategies for the treatment of infections associated with prosthetic joints. Curr Opin Investig Drugs 2005;6:185-190.

32. Dexter SJ, Pearson RG, Davies MC, et al. A comparison of the adhesion of mammalian cells and Staphylococcus epidermidis on fibronectin-modified polymer surfaces. J Biomed Mater Res 2001;56:222-227.

33. Subbiahdoss G, Kuijer R, Busscher HJ, van der Mei HC. Mammalian cell growth versus biofilm formation on bio- material surfaces in an in vitro post-operative contamination model. Microbiology 2010;156:3073-3078.

34. Subbiahdoss G, Fernandez IC, Domingues JF, et al. In vitro interactions between bacteria, osteoblast-like cells and macrophages in the pathogenesis of biomaterial-associated infections. PLoS One 2011;6:e24827.

35. Southwood RT, Rice JL, McDonald PJ, et al. Infection in experimental hip arthroplasties. J Bone Joint Surg Br 1985; 67:229-231.

36. Tande AJ, Patel R. Prosthetic joint infection. Clin Microbiol Rev 2014;27:302-345.

37. Busscher HJ, van der Mei HC, Subbiahdoss G, et al. Biomaterial-associated infection: Locating the finish line in the race for the surface. Sci Transl Med 2012;4:153rv10.

$$
\begin{array}{r}
\text { Address correspondence to: } \\
\text { Dr. Ramón Pérez-Tanoira } \\
\text { Department of Otorhinolaryngology- } \\
\text { Head and Neck Surgery } \\
\text { Helsinki University Hospital } \\
\text { and University of Helsinki } \\
\text { Haartmaninkatu } 4 \text { E, PO Box } 263 \\
\text { O0029 HUS, Helsinki } \\
\text { Finland }
\end{array}
$$

E-mail: ramontanoira@hotmail.com 